\title{
Methods of Foreign Language Teaching to Linguistically Gifted Students
}

\author{
Gulnara V. Gali ${ }^{1}$, Anastasiya V. Fakhrutdinova ${ }^{1} \&$ Askar I. Gali ${ }^{1}$ \\ ${ }^{1}$ Candidate of Pedagogics Sciences, Kazan Federal University, Kazan, Russia \\ Correspondence: Gulnara V. Gali, Candidate of Pedagogics Sciences, Kazan Federal University, Kazan, Russia. \\ E-mail: gulnaragali@mail.ru
}

Received: July 17, 2019

Accepted: November 18, 2019

Online Published: December 23, 2019

doi:10.5430/ijhe.v8n8p1

URL: https://doi.org/10.5430/ijhe.v8n8p1

\begin{abstract}
Purpose of the Study

The aim of this research is investigating the methods in Foreign Language Teaching To Linguistically Gifted Students.

\section{Methodology}

This is an analytical-logical research that has been done through content analysis. Also the data of this research have been obtained through the library.

\section{Results}

Communicative language teaching can be set as a set of principles related to language learning goals, how to learn a language with a learner, the types of classroom activities that best facilitate learning, and the role of the learner and teacher.
\end{abstract}

\section{Applications}

This article is useful for students and teachers.

Keywords: foreign language, linguistic giftedness, gifted students, competence

\section{Introduction}

The ability of children to speak two languages is extremely important and brings countless benefits to children. Teaching children a foreign language enhances their memory and enhances learning and understanding of different concepts in children. It is therefore advisable to start teaching foreign language to children at a younger age in order to raise more intelligent and talented children. The level of foreign language learning in children is much deeper than in other people, and it is recommended that foreign language learning be initiated from childhood (Gali, et al, 2018). Sagitova believed that "it is necessary to improve the content of education to solve the problem of the individualization of education" (Sagitova, R.R. (2014).

Teaching foreign language to Linguistically Gifted Students plays a very important role in their future lives, because by institutionalizing these skills and mastering them in a second language, they can accelerate their intellectual and intellectual development. In addition, fluency in another language creates better job opportunities and a brighter future for them (Davis \& Rimm, 2004; Taylor, 2000, Robinson, et al. 2007; Watts \& Watts, 1993). The aim of this research is determining Communicative Competence role in Foreign Language Teaching To Linguistically Gifted Students (Faraji \& Poshtdar, 2018).

\section{Methodology}

This is an analytical-logical research that has been done through content analysis. Also, the data of this research have been obtained through the library.

\section{Results}

There are three main ways to teach foreign language to language-proficient students that most educational institutions and systems use one of these three methods. Applying each of these methods depends on the age of the student, his or her educational system, and the parents' view of the language learning problem. In some ways the student learns foreign language faster and in some ways more freedom to choose learning (Fakhrutdinova \& Kondrateva, 2016). 
Induction method: In this model of learning, the gifted student in rabbits is completely immersed in another language environment. In bilingual kindergartens, educators speak a second language aimed at learning, and at school children spend at least half of their time learning the second language during the day. In the complete immersion method, which is used in a few schools, students learn all the subjects of mathematics, science and history in a second language. In this way, learning a second language, rather than being a subject for learning, is itself a means of teaching other subjects, and the child is subconsciously forced to learn it. Students who learn the language in this way are more successful in speaking the second language in a proper and complete dialect and reach higher levels of language learning (Winebrenner, 2000; Betts \& Kerscher, 1999).

Foreign Language Teaching Method in Elementary Schools: In this way, instead of teaching a foreign language to a child at the elementary level, the elementary school is taught to students in the same elementary years, along with other courses. In this method, the second language is introduced to the child as a learning subject, and typically the student spends 3 to 5 sessions per week learning the language. Children who start language learning at this age will be better off than children who first learn second language in later years. Introducing a second language in the early years of school where the child is eager to learn will speed up learning. Depending on the amount of time and effort spent in teaching this language to the child, the child may be able to speak a second language fluently in the future (Bogin, 1984; Gez, 1985; Raven, 2002).

Foreign Language Exploration: In this way, the student's age is a little higher, and this is more of a child's cognitive enhancement than a language education. In this way the second language and culture are presented to the child as a concept. The child speaks about different cultures and languages and more than one language may be offered to the child so that the student has a choice in learning a second language. In the earlier stages of this method, the second language structures are also taught to the student, but rather than emphasizing the eloquence of the language, the aim is to familiarize and provide information about the culture of the language spoken. (Galustyan, 2008 $S$ Rumyantseva, 2006, p. 15).

According to N. Proschyants, foreign language competence is understood as "a set of sociocultural, linguistic knowledge, skills and abilities, implemented by the subject adequately communicative task in a foreign language environment. As a basic concept, foreign language competence can be considered as a system of interacting elements, such as linguistic, linguocultural, sociocultural, professional foreign language, and communicative competence"( Proshyants, 2010).

The linguistic creativity of students is understood as "a set of abilities to create objectively and subjectively new ideal products using native and / or foreign language, producing oral and written statements based on divergent thinking with students' desire for creative speech activity" (Tyuleneva, 2012; Panfilova, 2015; Clasen \& Clasen, 1995).

\section{Discussion}

If talented students start teaching at an early age, students will learn the pronunciation of words correctly. In this way, they enjoy their opportunity for deep and conceptual language learning and without any hurry to learn the language. Their cognitive skills can be easily reinforced by teaching them foreign language and incorporating language concepts into their minds. This idea is reflected in the scientific work of foreign researchers: J. Kagan (2011), A. Passow (2009), J. Whitemore (2012), J. Renzulli (1982) and others (Rasaee et al, 2018).

The development of foreign language subtypes is influenced by various factors such as cognitive, individual, and social factors that have been investigated in a wide range of individual factors in language education studies, but so far in these studies, communication competencies as a factor No one has received serious attention. On the other hand, some linguistic interactions, which are among the key elements of the ability to use intermediate language skills, have the "threat of competence" feature. This makes the impact or relevance of communication competencies - which are directly related to individuals' ability and skill in managing and controlling emotions - very likely to be mediated by the ability to use language (Andreev, 2010; Wolfson, 2003; Dzhurinskiy, 1999; Panov, 2003; Savenkov, 2000; Ratner, 2009; Bogin, 1984).

\section{Conclusion}

Communicative language teaching can be set as a set of principles related to language learning goals, how to learn a language with a learner, the types of classroom activities that best facilitate learning, and the role of the learner and teacher.

In this regard, scientists differently determine the linguistic abilities underlying the linguistic talent: 
- as "individual psychological personality characteristics characterizing the speed and ease of acquiring linguistic knowledge, ensuring the speed of language acquisition and the effectiveness of language use in the communication process";

- as "a complex education that allows them mastering foreign language speech activity at the expense of basic cognitive mental processes and motivational and personal qualities of a person";

- as "special abilities to master a foreign language, which are a combination of individual psychological qualities of the students' intellect and their personality, determining ease of learning the material and its use in speech activity in a foreign language" ( Shibkova, 2000, p.166].

\section{Aknowledgement}

The work is performed according to the Russian Government Program of Competitive Growth of Kazan Federal University.

\section{References}

Betts, G. \& Kerscher, J. (1999). Autonomous learner model: Optimizing ability. Greeley, CO: Autonomous Learning Publications and Specialists.

Bogin, G.I. (1984). The model of linguistic personality in its relation to the varieties of texts (Doctoral dissertation). Leningrad.

Callahan, C. (2001). Evaluating learner and program outcomes in gifted education. In F.A. Karnes \& S.M. Bean (Eds.), Methods and materials for teaching the gifted, 253-300. Waco, TX: Prufrock Press.

Clasen, D. R. \& Clasen, R. E. (1995). Underachievement of highly able students and the peer society. Gifted and Talented International, 10, 67-76. https://doi.org/10.1080/15332276.1995.11672824

Davis, G. \& Rimm, S. (2004). Education of the gifted and talented (5th ed.). Boston, MA: Allyn and Bacon.

Fakhrutdinova, A.V. \& Kondrateva, I.G. (2016). Modeling Teacher's Multicultural Identity through Studying a Foreign Language: Proceedings of the IFTE $2016-2^{\text {nd }}$. International forum on teacher education, 12, 245-250. https://doi.org/10.15405/epsbs.2016.07.39

Gali, G., Shakhnina, I., Zagladina, E., Belyaeva, E., Dulmukhametova, G. \& Ibragimova, A. (2018). The Specificity of Gifted Students' Teaching: Overseas Data: Proceedings of INTCESS 2018- 5th International Conference on Education and Social Sciences, Istanbul, Turkey, 5-7 February (pp.25-31).

Galustyan, O.V. (2008). Pedagogical technology of monitoring of the formation of the foreign language communicative competence of students of a non-linguistic university (Doctoral dissertation). Voronezh.

Gez, N.I. (1985). Formation of communicative competence as an object of methodological research. Foreign languages at school, 2, 17-23.

Panfilova, V.M. (2015). Psychological and pedagogical conditions of the formation of foreign language competence of linguistically gifted students of a non-linguistic university (Doctoral dissertation). Yelabuga.

Proshyants, N.A. (2010). Formation of foreign linguistic competences in professional discourse. Research work, 3, 34-38.

Raven, J. (2002). Competence in modern society: Identification, development and implementation. Translation from English. Moscow.

Robinson, A., Shore, B. \& Enersen, D. (2007). Best Practices in gifted education: An evidence-based guide. Waco, TX: Prufrock.

Rumyantseva, M.V. (2006). Teaching a foreign language of linguistically gifted schoolchildren in the context of additional education (Doctoral dissertation). St. Petersburg.

Sagitova, R.R. (2014). Training students to be autonomous learners. International Journal of Humanities Education, 12, 27-34. https://doi.org/10.18848/2327-0063/CGP/v12i01/43817

Shibkova, O.S. (2000). Diagnostics and the formation of cognitive components of the linguistic abilities of high school students with in-depth study of the English language (Doctoral dissertation). Stavropol.

Taylor, S. (2000). Assessment and evaluation. Retrieved September 15, 2003. 
Tyuleneva, T.V. (2012). Formation of linguistic creativity of students of non-linguistic specialties (Doctoral dissertation). Volgograd.

Watts, M. \& Watts, D. (1993). Teacher research, action research: The logo action research collaborative. Educational Action Research, 1(1), 35-63. https://doi.org/10.1080/0965079930010104

Winebrenner, S. (2000). Gifted students need an education, too. Educational Leadership, September, 52-56.

Rasaee, F., Gholami, J., \& Abbasian, G. R. (2018). Short-vs. Long-Term Effects of Reactive Incidental Focus on Form in Free Discussion EFL Classes. Research in Applied Linguistics, 9(2), 3-23.

Faraji, G., \& Poshtdar, A. M. (2018). Armenian myths and legends and their impact on Armenian beliefs and literature. UCT Journal of Social Sciences and Humanities Research, 6(04), 32-44. 